\title{
The effect of intermittent umbilical cord occlusion on insulin-like growth factors and their binding proteins in preterm and near-term ovine fetuses
}

\author{
L R Green ${ }^{1}$, Y Kawagoe ${ }^{2}$, D J Hill ${ }^{1,3}$, B S Richardson ${ }^{1,2}$ \\ and V K M Han ${ }^{2,4}$
}

${ }^{1}$ MRC Group in Fetal and Neonatal Health and Development, Department of Physiology, The Lawson Research Institute, and The Child Health Research Institute, The University of Western Ontario, London, Ontario N6A 4V2, Canada

${ }^{2}$ Department of Obstetrics and Gynaecology, The Lawson Research Institute, and The Child Health Research Institute, The University of Western Ontario, London, Ontario N6A 4V2, Canada

${ }^{3}$ Department of Medicine, The Lawson Research Institute, and The Child Health Research Institute, The University of Western Ontario, London, Ontario N6A 4V2, Canada

${ }^{4}$ Department of Paediatrics, The Lawson Research Institute, and The Child Health Research Institute, The University of Western Ontario, London, Ontario N6A 4V2, Canada

(Requests for offprints should be addressed to L R Green, Centre for Fetal Origins of Adult Disease, 887(F) Princess Anne Hospital, Coxford Road, Southampton SO16 5YA, UK; Email: LucyRGreen@hotmail.com)

\begin{abstract}
Intermittent umbilical cord compression with resultant fetal hypoxia can have a negative impact on fetal growth and development. Insulin-like growth factors (IGFs) and their binding proteins (IGFBPs) are the most important regulators of fetal growth. In preterm (107-108 days of gestation) and near-term (128-131 days of gestation) ovine fetuses, we have determined the effect of intermittent umbilical cord occlusion (UCO) over a period of 4 days on the profile and expression of IGFs and IGFBPs. In experimental group animals (preterm $n=7$; near term $n=7$ ) UCOs were carried out by complete inflation of an occluder cuff (duration $90 \mathrm{~s}$ ) every $30 \mathrm{~min}$ for $3-5 \mathrm{~h}$ each day, while control fetuses (preterm $n=7$; near term $n=7$ ) received no UCOs. Ewes were euthanized at the end of day 4, and fetal heart, lung, kidney, liver, skeletal muscle and placenta were collected. During $\mathrm{UCOs}, \mathrm{PO}_{2}$ fell (by $\sim 13 \mathrm{mmHg}$ ), $\mathrm{pH}$ fell (by $\sim 0.05$ ) and $\mathrm{PCO}_{2}$ increased (by $\sim 7 \mathrm{mmHg}$ ), and changed to a similar extent in both preterm and near-term groups. In both preterm and near-term groups, there was no difference in fetal body or organ weight between UCO and control fetuses. No significant changes were observed in plasma IGF-I and -II
\end{abstract}

concentrations or IGFBP-1, $-2,-3$ or -4 levels throughout the 4-day study at either gestational age. In the preterm group UCO fetuses, IGF-II mRNA $(1 \cdot 2-6 \cdot 0 \mathrm{~kb})$ levels were lower in fetal lung $(33 \%, P<0 \cdot 05)$, heart $(54 \%$, $P<0 \cdot 01)$ and skeletal muscle $(29 \%, P<0 \cdot 05)$, but there were no differences in IGF-I mRNA levels $(7 \cdot 3 \mathrm{~kb})$; IGFBP-2 mRNA $(1.5 \mathrm{~kb})$ levels were lower in the right lobe of the liver $(42 \%, P<0 \cdot 05)$ and kidney $(22 \%$, $P<0 \cdot 01)$, but higher in the heart $(72 \%, P<0 \cdot 01)$, while IGFBP-4 $(2 \cdot 4 \mathrm{~kb})$ levels were lower in skeletal muscle $(21 \%, P<0 \cdot 01)$. In the near-term group UCO fetuses, IGFBP-2 mRNA levels were greater in the placenta $(39 \%, P<0 \cdot 05)$. Thus, intermittent UCO as studied has a greater effect on the expression of genes encoding certain peptides of the fetal IGF system in selected tissues in preterm fetuses than that in near-term fetuses. Altered IGFBP-2 mRNA levels with reduced IGF-II mRNA levels in selected tissues may mediate changes in growth and/or differentiation that might become apparent if the length of the UCO study were extended.

Journal of Endocrinology (2000) 166, 565-577

\section{Introduction}

In human pregnancies, near-term 'variable type' fetal heart rate (FHR) decelerations, indicative of umbilical cord compression and resultant fetal hypoxaemia, are seen in $2-10 \%$ of FHR tracings (Anyaegbunam et al. 1986, Dawes et al. 1993) and can be associated with an increased incidence of neonatal acidosis, low Apgar (see Jennett et al. 1981) scores and nuchal cord complications at the time of delivery. We have recently reported that infants with the umbilical cord around the neck at birth are smaller than those without cord complications, and also that their placentas are larger (Osak et al. 1997). Nuchal cord encirclements are detected several weeks prior to labour 


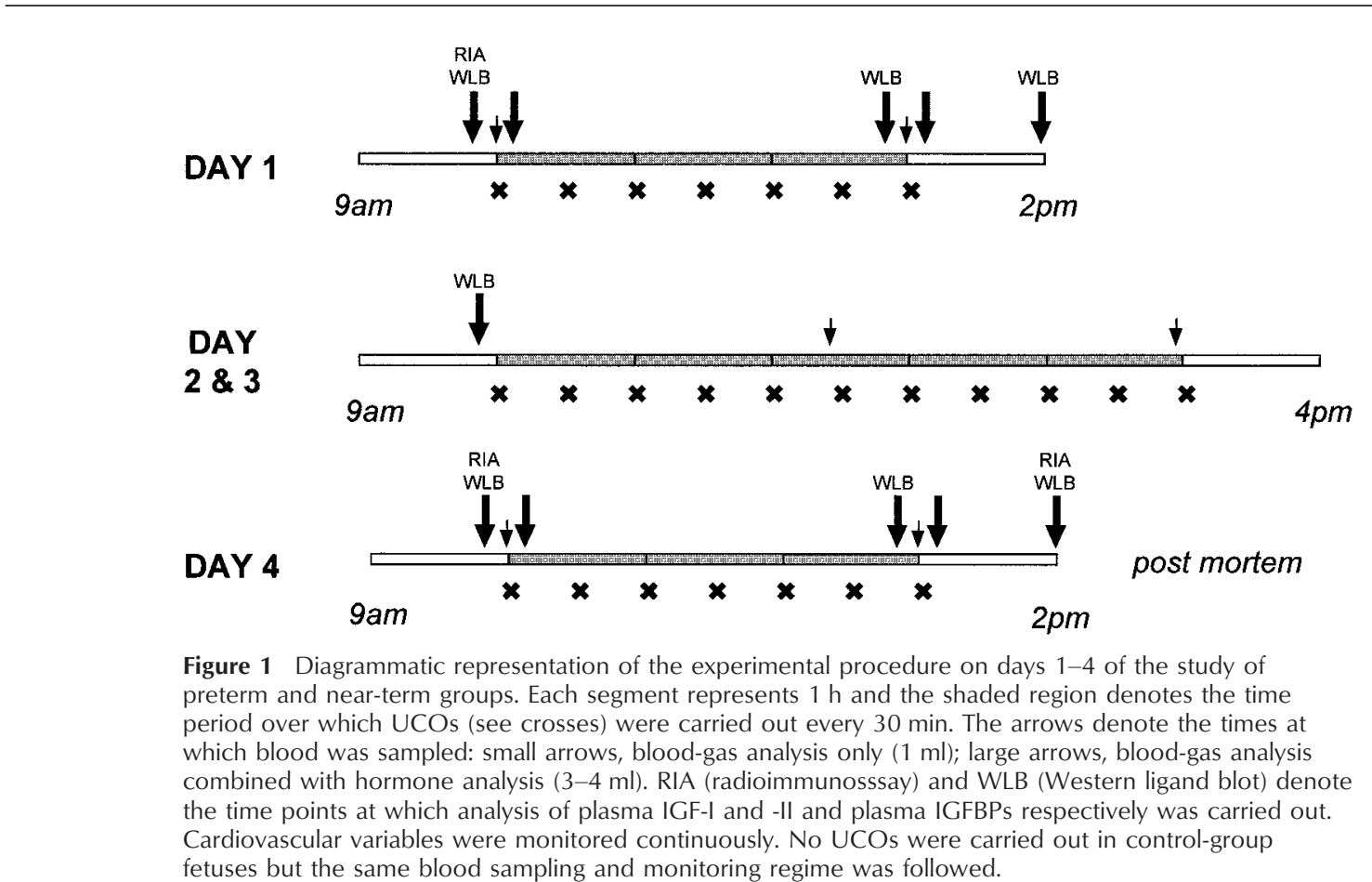

and delivery (Collins et al. 1995) and therefore the mechanisms underlying the decreased birth weight are likely to involve a reduction in umbilical blood flow and thus altered nutrient and/or oxygen delivery. The increased placental weight may represent an adaptive overgrowth to sustain nutrient supply, as seen in humans with mild hypoxaemia at high altitude (see Barker 1994) and in some instances of maternal undernutrition in sheep (McCrabb et al. 1991).

Insulin-like growth factors (IGF-I and IGF-II) are polypeptide growth factors with potent mitogenic, metabolic and differentiating actions, and play an important role in the regulation of fetal growth (Han \& Hill 1994). Insulin-like growth factors are synthesized by different fetal tissues and are present in all extracellular fluids bound to one or more of a family of IGF-binding proteins (IGFBPs). These binding proteins act as carrier/storage proteins of IGFs in the circulation, as modulators of the biological actions of IGFs, and may even have cellular functions independent of IGFs (Rosenfeld 1997). The ubiquity and the spatial and temporal pattern of expression of IGF and IGFBP genes in fetal tissues are appropriate for their principle role in the regulation of fetal growth. Clinical studies of intrauterine growth restriction (IUGR) suggest that changes in IGF and IGFBPs are important biochemical markers of the degree of growth restriction and are causally related to IUGR (Wang et al. 1991, Verhaeghe et al. 1993, Giudice et al. 1995). Experimental studies with induced IUGR in rats (Vileisis \& D’Ercole 1986, Straus \& Takemoto 1990) and sheep
(Owens et al. 1994) demonstrate that fetal growth restriction is variably associated with a decrease in circulating and/or tissue IGF-I and -II, and an increase in IGFBP-1. In ovine fetuses subjected to sustained hypoxaemia over hours to days, plasma IGF-I is reduced (Iwamoto et al. 1992), whereas plasma IGFBP-1 is increased and IGFBP-2 is reduced with corresponding alterations in tissue IGFBP mRNA levels (McLellan et al. 1992). These changes are associated with a reduction in the rate of DNA synthesis in specific organs and tissues (Hooper et al. 1991, Asano et al. 1997). A reduction in fetal growth, with associated changes in IGFs and IGFBPs, is likely to constitute tissue-specifc energy expenditure adaptations in the face of an altered substrate and/or oxygen supply and could be mediated, in part, by endocrine changes involving catecholamines (Hooper et al. 1994) or cortisol (Braems et al. 1998), for example.

In the present study, we determined the effect of intermittent umbilical cord occlusion (UCO) with severe but reversible hypoxia and no cumulative acidosis (to ensure longer term survival) on circulating levels of IGFs and IGFBPs and on tissue IGF and IGFBP mRNA abundance. We hypothesized that changes in IGFs and IGFBPs are biochemical markers that precede changes in organ and tissue weights. Chronically catheterized ovine fetuses were studied both at preterm and near term to determine whether there was any developmental change in the fetal IGF and IGFBP responses to intermittent hypoxic insults. 
Table 1 Morphometric data, age at post-mortem and gender in preterm and near-term group fetuses. Organ weights are expressed as a percentage of body weight. All values are means \pm S.E.M. Within preterm and near-term groups, the control and UCO fetuses were well matched in terms of age and gender. In addition, there were no differences between control and occluded fetuses in terms of body weight or brain, liver and heart weights expressed as a percentage of body weight

\begin{tabular}{|c|c|c|c|c|}
\hline & Control & & UCO & \\
\hline & Preterm & Near term & Preterm & Near term \\
\hline Age (days) & 114 & 136 & 114 & 136 \\
\hline Sex & $3 \mathrm{~F}, 4 \mathrm{M}$ & $3 \mathrm{~F}, 4 \mathrm{M}$ & $4 \mathrm{~F}, 3 \mathrm{M}$ & $4 \mathrm{~F}, 3 \mathrm{M}$ \\
\hline Body weight (BW, kg) & $2 \cdot 0 \pm 0 \cdot 2$ & $3 \cdot 9 \pm 0 \cdot 2$ & $2 \cdot 0 \pm 0 \cdot 2$ & $4 \cdot 5 \pm 0 \cdot 2$ \\
\hline Brain (\% BW) & $1 \cdot 8 \pm 0 \cdot 1$ & $1 \cdot 3 \pm 0 \cdot 1$ & $1 \cdot 9 \pm 0 \cdot 2$ & $1 \cdot 2 \pm 0 \cdot 1$ \\
\hline Liver (\% BW) & $4 \cdot 4 \pm 0 \cdot 2$ & $2 \cdot 2 \pm 0 \cdot 2$ & $4 \cdot 3 \pm 0 \cdot 3$ & $2 \cdot 5 \pm 0 \cdot 1$ \\
\hline Heart (\% BW) & $0 \cdot 8 \pm 0 \cdot 0$ & $0 \cdot 7 \pm 0 \cdot 0$ & $0 \cdot 7 \pm 0 \cdot 1$ & $0 \cdot 6 \pm 0 \cdot 0$ \\
\hline
\end{tabular}

\section{Materials and Methods}

\section{Surgical preparation}

Surgery and experiments were conducted in accordance with the Canadian Council on Animal Care regulations. Pregnant mixed western ewes (term $=147 \mathrm{~d}$ ) were instrumented, using sterile technique, under general anaesthesia (1 g thiopental sodium in solution intravenously for induction (Abbott Laboratories Ltd, Montreal, Canada), followed by $1-1.5 \%$ halothane in $\mathrm{O}_{2}$ for maintenance) between 107 and 108 days of gestation (preterm group: control $n=7$; UCO $n=7$ ) and between 128 and 131 days of gestation (near-term group: control $n=7$; UCO $n=7$ ). Polyvinyl catheters filled with heparinized saline were placed in left and right brachial arteries, a brachial vein and the amniotic cavity. Stainless-steel electrodes were sewn onto the fetal chest for monitoring using an electrocardiograph. In UCO fetuses, an inflatable occluder cuff (OC14, In Vivo Metric, Healdsburg, California, USA) was positioned around the proximal portion of the umbilical cord and was secured to the abdominal skin. The volume that was required for complete occluder cuff inflation was determined at surgery. A catheter was placed in a maternal femoral vein for administration of fluids and transfusion of maternal blood to the fetus. Ewes received a broadspectrum, long-acting antibiotic immediately prior to surgery (1.2 g oxytetracycline intramuscularly; Rogar, STB Inc., London, Canada). Following surgery, ewes were given an analgesic (75 mg flunixin intramuscularly; Schering, Pointe-Claire, Canada) and fluids (500-1000 ml saline intravenously).

A 3-day postoperative recovery period was allowed prior to experimentation, during which daily antibiotic treatment was given to the fetus (1 million IU penicillin G sodium intravenously; Novopharm Ltd, Toronto, Canada) and introduced into the amniotic cavity (1 million IU penicillin $\mathrm{G}$ sodium); fetal arterial blood was collected for blood-gas analysis.

\section{Experimental procedure and tissue collection}

Both the preterm (111-116 days of gestation) and the near-term (132-138 days of gestation) groups were studied on four successive days (Fig. 1). In experimental fetuses, following a $1 \mathrm{~h}$ control period (0900 to $1000 \mathrm{~h}$ each day), either 7 (days 1 and 4) or 11 (days 2 and 3) UCOs were carried out by complete inflation of the occluder cuff ( $\sim 3 \mathrm{ml}$ saline) for $90 \mathrm{~s}$ every $30 \mathrm{~min}$ (Fig. 1). The time of day for study, and the duration, frequency and intensity of the UCO insult administered to the preterm and nearterm group fetuses were similar. In control fetuses no UCOs were carried out.

In control and experimental fetuses, blood was sampled at predetermined intervals throughout the 4 day protocol (arrows, Fig. 1). 'Pre-UCO' samples were taken 5 min before inflation of the occluder cuff and 'post-UCO' samples were taken 5 min after release of the occluder cuff. Blood samples during UCOs (days 1 and 4 only) were always taken $60 \mathrm{~s}$ into the $90 \mathrm{~s}$ occlusion period (blood-gas analysis only). 'Recovery' blood samples were taken at the end of a $1 \mathrm{~h}$ recovery period (days 1 and 4 only). Blood-gas composition and $\mathrm{pH}$ were analysed at all fetal bloodsampling time points. Plasma for subsequent hormonal analysis was collected at a selection of time points only (3-4 ml; larger arrows in Fig. 1); Fig. 1 shows where this included analysis of plasma IGFs by radioimmunoassay (RIA) and of IGFBPs by Western ligand blotting. The volume of fetal blood taken was replaced with an equal volume of maternal venous blood at the end of study each day. Fetal arterial blood samples were collected on ice and analysed for blood-gas composition (ABL 500 bloodgas analyser and OSM2 haemoximeter, Radiometer, Copenhagen, Denmark) or spun at $4{ }^{\circ} \mathrm{C}(10 \mathrm{~min}$ at $\times 2000 \mathrm{~g}$, TJ-6; Beckman, Fullerton, CA, USA) and the plasma stored in separate aliquots at $-20{ }^{\circ} \mathrm{C}$ for subsequent IGF and IGFBP analysis.

After the $1 \mathrm{~h}$ recovery period on day 4, ewes were killed with an overdose of barbiturate $(30 \mathrm{mg}$ sodium 


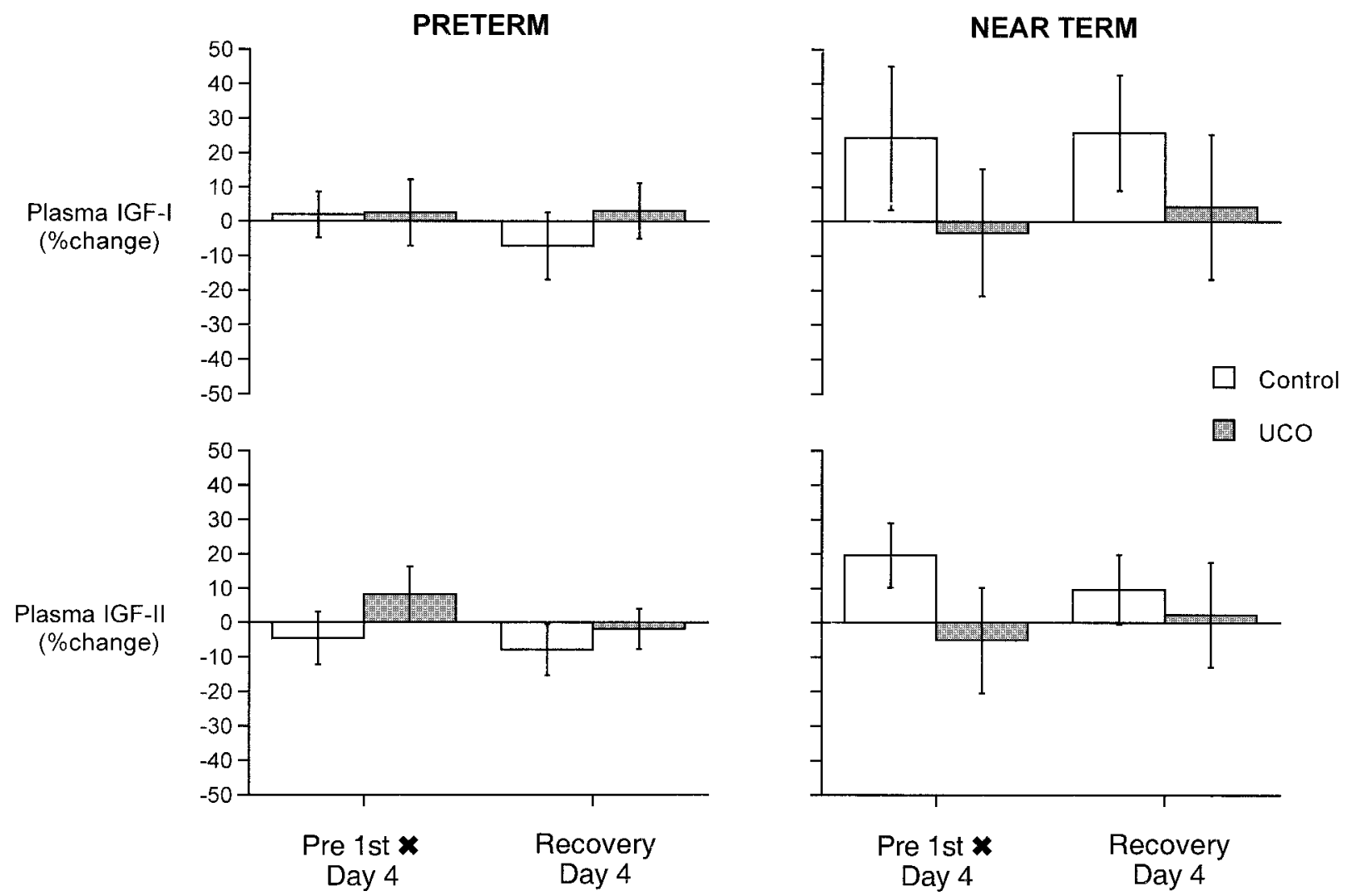

Figure 2 Percentage change in plasma IGF-I and IGF-II from pre-1st UCO (crosses) day 1 in preterm and near-term control ( $\square$ ) and UCO (ם) fetuses. Values are means \pm S.E.M. values. Intermittent UCO did not alter plasma IGFs over the 4-day study.

pentobarbital intravenously; MTC Pharmaceuticals, Cambridge, Canada) and the fetus was delivered immediately. At this time, the location and function of the umbilical occluder cuff was confirmed. Fetal heart, lung, liver, kidney, skeletal muscle and cotyledons were harvested, weighed, frozen rapidly in liquid nitrogen and stored at $-70{ }^{\circ} \mathrm{C}$ until analysis.

\section{cDNA probes}

Ovine-specific cDNAs encoding IGF-I, IGF-II, IGFBP-1, IGFBP-2, IGFBP-3 and IGFBP-4 were cloned in our laboratory. The IGF-I cDNA was the $540 \mathrm{bp}$ SacI-BamHI fragment encoding the sheep prepro-IGF-I (McLellan et al. 1992), the IGF-II cDNA was the $863 \mathrm{bp}$ EcoRI fragment encoding the sheep prepro-IGF-II (Delhanty \& Han 1993), the IGFBP-1 cDNA was the $870 \mathrm{bp}$ EcoRI-BamHI fragment encoding the mature peptide of the sheep IGFBP-1 (McLellan et al. 1992), the IGFBP-2 cDNA was the $784 \mathrm{bp}$ SmaI-SacI fragment encoding the midregion of the sheep IGFBP-2 (Delhanty \& Han 1992), the IGFBP-3 cDNA was the $1.6 \mathrm{bp}$ XbaI-HindIII fragment encoding prepro-IGFBP-3 (Hayatsu et al. 1994), and the IGFBP-4 cDNA was the 784 bp BamHI-EcoRI fragment (our unpublished observations).

\section{Northern blotting}

Total RNA was isolated using a modification of the singlestep acid guanidium thiocyanate-phenol-chloroform extraction method (Chomczynski \& Sacchi 1987). The integrity of RNA was checked on non-denaturing 1\% agarose gels and the sample concentration was determined by spectrophotometric absorbance at $260 \mathrm{nM}$. Individual total RNA samples $(20 \mu \mathrm{g})$ and an RNA ladder $(3 \mu \mathrm{g}$, 0.24-9.5 kb; Gibco-BRL, Life Technologies, Burlington, Ontario, Canada) were subjected to Northern blot analysis as described previously (Delhanty \& Han 1993). Blots were hybridized with ${ }^{32} \mathrm{P}$-labelled ovine cDNA probe $\left(1 \times 10^{6}\right.$ c.p.m. $/ \mathrm{ml}$ ) at $42^{\circ} \mathrm{C}$ and washed at a maximum stringency of $0 \cdot 1 \times \mathrm{SSC} / 0 \cdot 1 \% \operatorname{SDS}(2 \times 30 \mathrm{~min})$ at $42{ }^{\circ} \mathrm{C}$. The blots were exposed to X-ray film (XAR or BMR film with intensifying screens; Eastman Kodak, Rochester, NY, USA). Prior to hybridization with a different probe, the blots were stripped $(3 \times 20 \mathrm{~min})$ in $0 \cdot 01 \times \mathrm{SSC} / 0 \cdot 1 \% \mathrm{SDS}$ at $80-90{ }^{\circ} \mathrm{C}$. All blots were probed with ${ }^{32} \mathrm{P}$-labelled mouse 

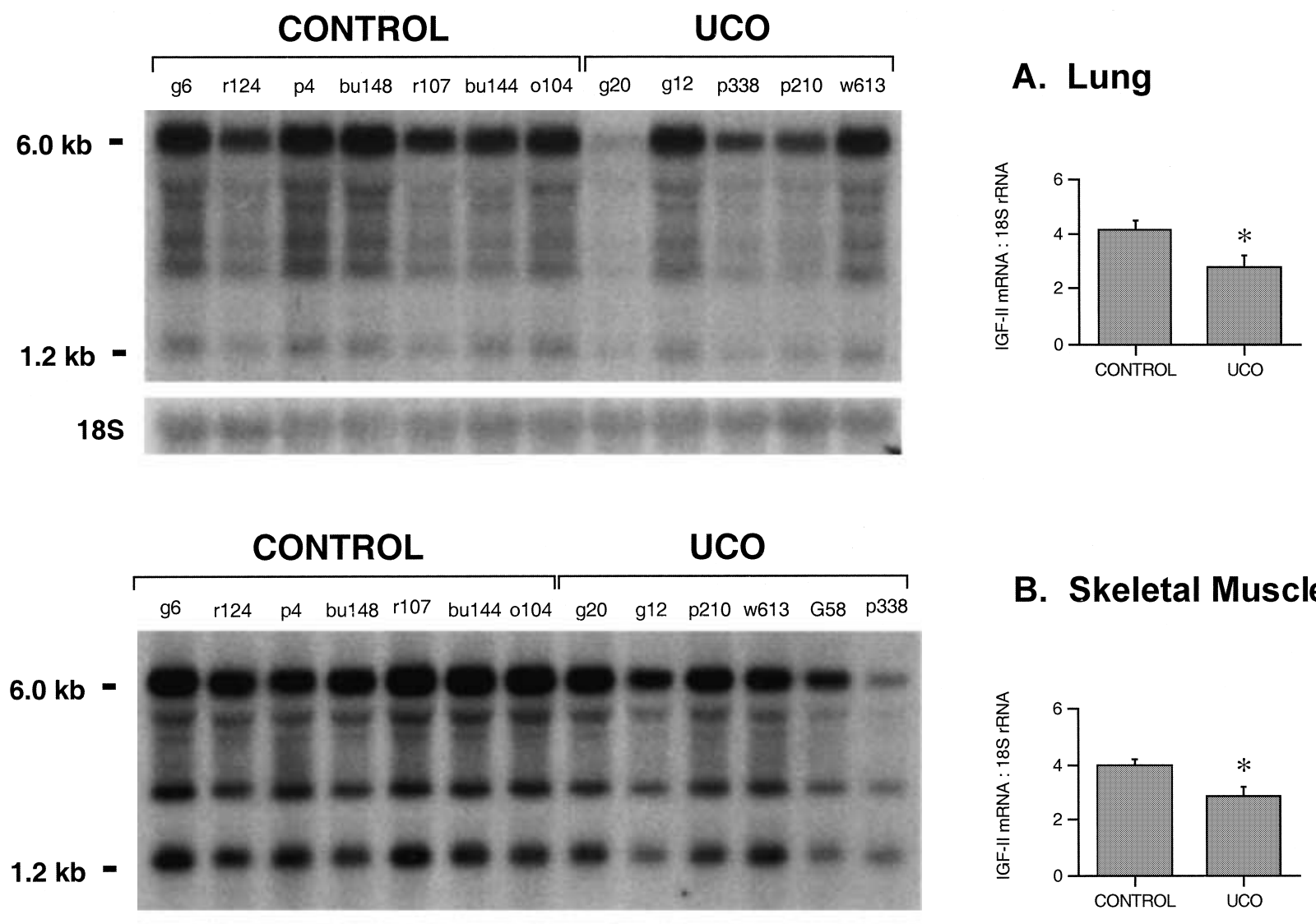

\section{B. Skeletal Muscle}

$18 S$

Figure 3 Northern blot hybridization (images on the left-hand side) of total RNA ( $20 \mu \mathrm{g}$ per lane) from preterm lung (A) and skeletal muscle (B) of control and UCO fetuses with ${ }^{32}$ P-labelled ovine IGF-II (upper panel) and 18S rRNA (lower panel) cDNA. A number of IGF-II mRNA transcripts were observed between $\sim 1.2$ and $6.0 \mathrm{~kb}$ in both tissue types. Graphs show that the abundance of IGF-II mRNA (all transcripts) expressed as a ratio to $18 \mathrm{~S}$ rRNA was lower in UCO fetuses than in control fetuses $\left({ }^{*} P<0 \cdot 05\right.$ ), according to densitometric analysis (means \pm S.E.M. values). Numbers above lanes identify individual animals. Note: certain total RNA samples from the lung and skeletal muscle of the UCO group (two and one, respectively) were consistently found to be degraded and therefore were not included in the Northern blot.

18S rRNA cDNA to determine the consistency of sample loading and transfer.

\section{Western ligand blotting}

The profiles and relative levels of IGFBPs in fetal sheep plasma were determined by the Western ligand blot method, as previously described (McLellan et al. 1992). Analysis was carried out on $10 \mu$ plasma sampled pre-1st UCO, pre-7th UCO and at the end of the recovery hour on days 1 and 4, and pre-1st UCO on days 2 and 3. Blots were hybridized overnight at $4{ }^{\circ} \mathrm{C}$ with ${ }^{125}$ I-labelled IGF-II (200 000 c.p.m./blot), washed and exposed to X-ray film (XAR and BMR with intensifying screens) at $-70{ }^{\circ} \mathrm{C}$.

\section{IGF-I and IGF-II radioimmunoassay}

The IGF-I and IGF-II concentrations were determined in plasma by the modification of a previously described RIA method validated for fetal plasma (McLellan et al. 1992). Plasma samples $(100 \mu \mathrm{l})$ from pre-1st-UCO days 1 and 4 and from the end of the recovery hour on day 4 were analysed. The IGFs in plasma samples were separated from IGFBPs using acid extraction followed by Sephadex G50 gel chromatography (Amersham Pharmacia Biotech, Piscataway, NJ, USA). The absence of IGFBPs from IGF-containing fractions was confirmed by Western ligand blot analysis of the column eluent from a nonexperimental fetal plasma sample of an equivalent gestational age group. 
Table 2 Summary of changes in IGF and IGFBP mRNA abundance in preterm and near-term fetuses following repetitive UCO

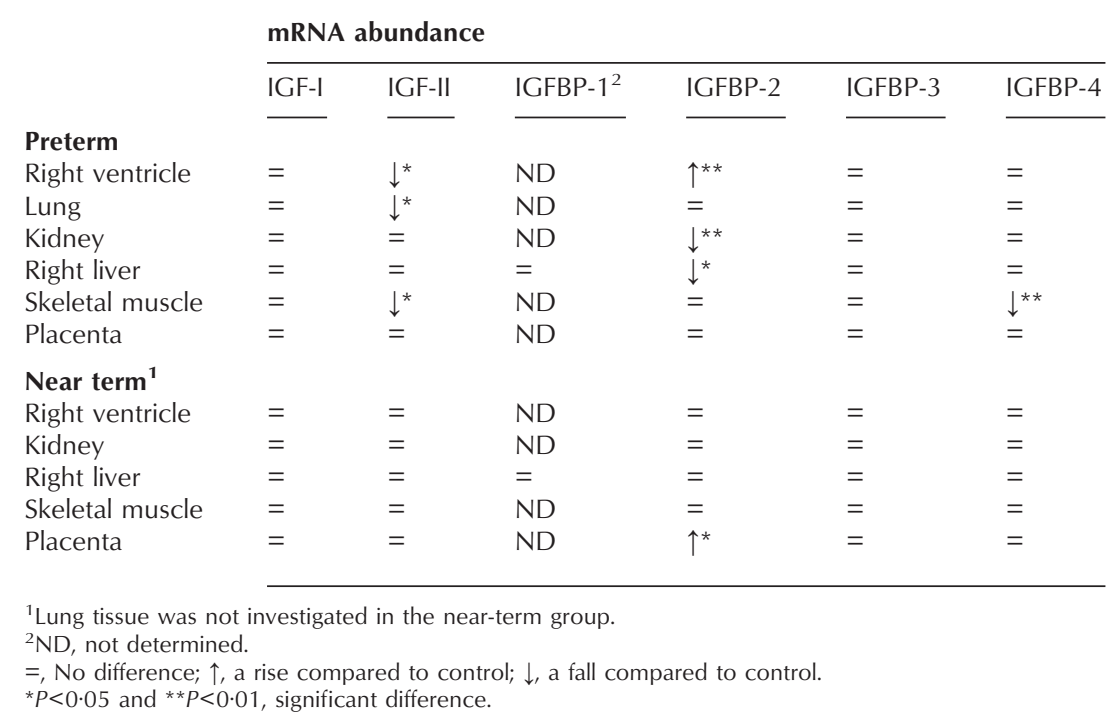

\section{Data analysis}

In preterm and near-term groups, the blood gas and $\mathrm{pH}$ responses during periods of $\mathrm{UCO}$ on days 1 and 4, and in pre-1st UCO values over the course of the 4-day study, were analysed using a repeated measures ANOVA followed by a Student's $t$-test with the Bonferroni method of correction for multiple comparisons made at a given point in time.

Plasma IGFBPs on Westerm ligand blots, and IGF and IGFBP mRNAs on Northern blots, were quantified by scanning laser densitometry (IP Lab Gel, Signal Analytics Corp., Vienna, VA, USA). For Northern blots, the relative density of bands (arbitrary units per $\mathrm{mm}$ ) were expressed as a ratio to the relative density of the corresponding $18 \mathrm{~S}$ band and statistical analysis was carried out between control and UCO fetuses using the Student's unpaired $t$-test. For Western ligand blots, the relative densities of IGFBPs were expressed as a ratio to the relative density of the IGF-II receptor, which was known not to change over the period of gestation in the present study or to be altered during $24 \mathrm{~h}$ of continuous hypoxia (McLellan et al. 1992, Delhanty \& Han 1993); a statistical analysis was conducted on values over the course of the 4-day protocol, using two-way ANOVA for repeated measures. Plasma levels of IGF-I and IGF-II were analysed between groups and over time using two-way ANOVA for repeated measures. Values are expressed as means \pm S.E.M. values throughout. Statistical significance was accepted at $P<0 \cdot 05$.

\section{Results}

Fetal blood gases and $\mathrm{pH}$

In both preterm and near-term groups, UCO caused a large decline in fetal arterial $\mathrm{PO}_{2}$ (preterm: $24 \cdot 1 \pm 0 \cdot 5$ to
$6.7 \pm 0.8 \mathrm{mmHg}, \quad P<0.01$; near term: $19.9 \pm 0.7$ to $7 \cdot 6 \pm 0.8 \mathrm{mmHg} P<0 \cdot 01), \mathrm{O}_{2}$ saturation (preterm: $68 \cdot 7 \pm 1 \cdot 6$ to $12 \cdot 4 \pm 2 \cdot 5 \%, P<0 \cdot 01$; near term: $53 \cdot 4 \pm 2 \cdot 2$ to $11 \cdot 0 \pm 1 \cdot 8 \%, P<0 \cdot 01$ ) and $\mathrm{pH}$ (preterm: $7 \cdot 36 \pm 0 \cdot 00$ to $7 \cdot 30 \pm 0 \cdot 01, P<0 \cdot 01$; near term: $7 \cdot 35 \pm 0 \cdot 01$ to $7 \cdot 30 \pm$ $0 \cdot 01, P<0 \cdot 01$ ), and a rise in $\mathrm{PCO}_{2}$ (preterm: $52 \cdot 3 \pm 0 \cdot 6$ to $60 \cdot 2 \pm 1 \cdot 0 \mathrm{mmHg}, P<0 \cdot 01$; near term: $53.5 \pm 0.7$ to $61 \cdot 1 \pm 1 \cdot 1 \mathrm{mmHg}, P<0 \cdot 01)$ as studied on days 1 and 4 ; a return to control values occurred after occluder release.

Baseline (pre-1st UCO) measurements of blood gases and $\mathrm{pH}$ were unaltered over the course of the 4-day study in control and UCO fetuses, apart from a small fall in $\mathrm{pH}$ in preterm (day 1 versus day 4: control, $7 \cdot 37 \pm 0 \cdot 01$ to $7 \cdot 32 \pm 0 \cdot 01, P<0 \cdot 01 ; \mathrm{UCO}, 7 \cdot 38 \pm 0 \cdot 01$ to $7 \cdot 34 \pm 0 \cdot 02$, $P<0 \cdot 01$ ) and near term (day 1 versus day 4: control, $7 \cdot 36 \pm 0 \cdot 01$ to $7 \cdot 34 \pm 0 \cdot 00, P<0 \cdot 05 ;$ UCO, $7 \cdot 39 \pm 0 \cdot 02$ to $7 \cdot 35 \pm 0 \cdot 01, P<0 \cdot 05)$ groups, and in $\mathrm{O}_{2}$ saturation in the UCO near-term fetuses only (day 1 versus day 4: $58 \cdot 4 \pm 3 \cdot 5$ to $49 \cdot 4 \pm 4 \cdot 2 \%, P<0 \cdot 01)$.

\section{Fetal organ and body weights}

In preterm and near-term groups, we measured fetal body weight, and brain, liver and heart weights at the time of post-mortem. In both groups, there were no differences between control and UCO fetuses in terms of body weight, or brain, liver or heart weight expressed as a percentage of fetal body weight (Table 1).

\section{Fetal plasma IGFs}

There was no significant effect of 4 days of intermittent UCO on plasma IGF-I or IGF-II in either preterm or near-term groups (Fig. 2). 
A
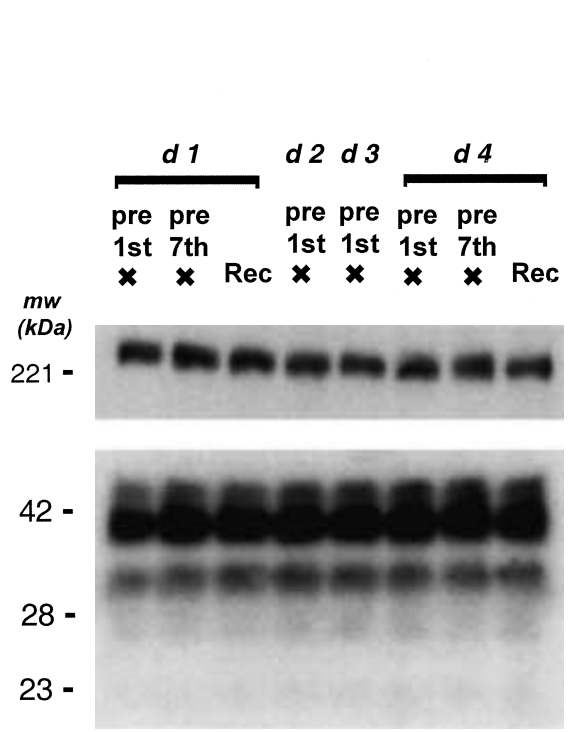

B
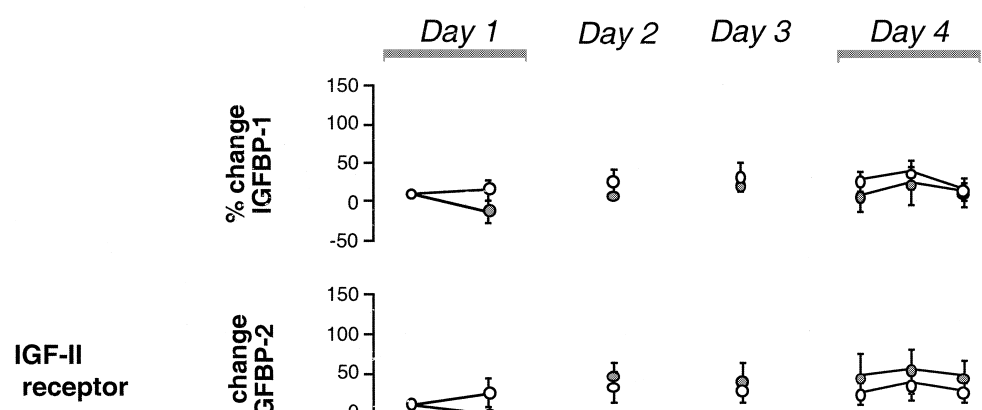

IGFBP-3

IGFBP-2

IGFBP-1

IGFBP-4

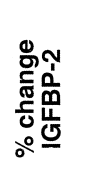
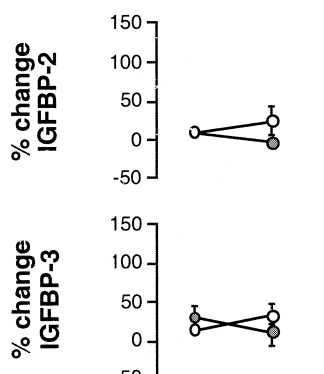

$\$$
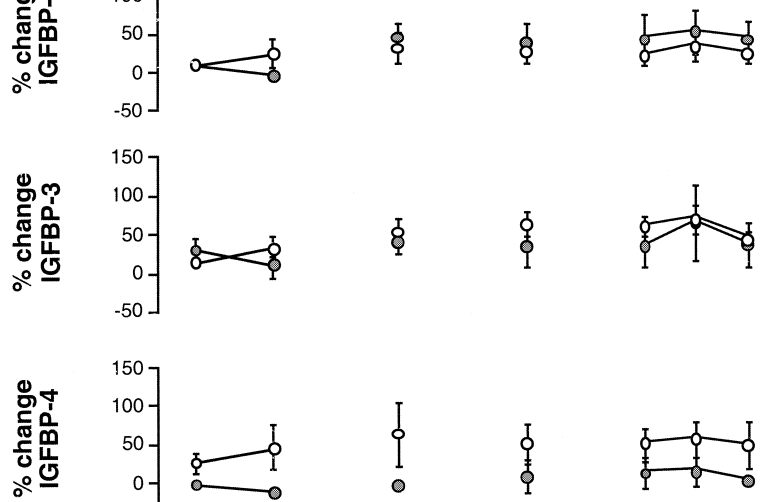

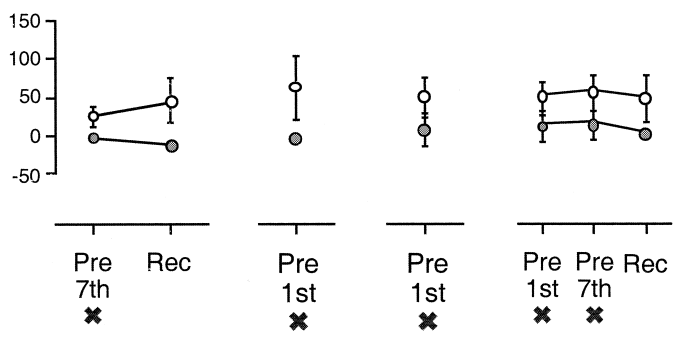

Figure 4 Preterm-group plasma IGFBP levels throughout the 4-day study. (A) Western ligand blot from a representative preterm fetus showing samples taken on days 1-4 (d1-d4) during pre-UCO (crosses) and recovery periods. (B) Values from densitometric analysis of ligand blots expressed as a ratio to plasma IGF-II receptor and as a percentage change from day 1 pre-1st (crosses) values in control $(O)$ and UCO $(-)$ fetuses. Values are means \pm S.E.M. values. Plasma IGFBPs were unaltered over the 4-day study period in preterm and near-term groups (data not shown).

\section{Tissue IGF $m R N A$ s}

IGF-I mRNA was detected in all preterm and near-term tissues examined by Northern blotting (heart, lung, kidney, liver, skeletal muscle and placenta). On the basis of autoradiographic exposure times, IGF-I mRNA was of lower abundance than IGF-II mRNA in all tissues examined. There were no differences in IGF-I mRNA levels between control and UCO fetuses in preterm or near-term groups.

IGF-II mRNA was detected in all preterm and nearterm tissues (heart, lung, kidney, liver, skeletal muscle and placenta). Five IGF-II mRNA transcripts (between $1 \cdot 2$ and $6.0 \mathrm{~kb}$ ) were easily identified and densitometric analysis of these transcripts as a whole demonstrated significantly lower levels in the right ventricle (54\%), lung (33\%; Fig. $3 \mathrm{~A})$ and skeletal muscle (29\%; Fig. 3B) of the UCO compared with control fetuses from the preterm, but not the near-term, group (Table 2).

\section{Fetal plasma IGFBPs}

In Western ligand blots from both preterm and near-term fetuses, we identified six protein species with the ability to bind to ${ }^{125}$ I-IGF-II (Fig. 4A). The profiles were similar to those observed previously in the fetal sheep (McLellan et al. 1992, Delhanty \& Han 1993), in which it was noted that these bands correspond to the IGF-II receptor $(\sim 220 \mathrm{kDa})$, IGFBP-3 (glycosylated $(\sim 41 \mathrm{kDa})$ and non-glycosylated $(\sim 38 \mathrm{kDa}))$, IGFBP-2 $(\sim 34 \mathrm{kDa})$, IGFBP-1 ( $30 \mathrm{kDa})$ and IGFBP-4 $(\sim 23 \mathrm{kDa})$.

In preterm and near-term groups, plasma IGFBP levels over the course of the 4-day protocol, expressed as a percentage change from the level measured pre-1st UCO on day 1 and as a ratio to the corresponding IGF-II receptor band showed no significant changes either temporally or between control and UCO fetuses (Fig. 4B).

\section{Tissue IGFBP $m R N A s$}

IGFBP-2, -3 and -4 mRNAs were detected in all of the tissues examined (heart, lung, kidney, liver, skeletal muscle and placenta). Previous studies have shown that IGFBP-1 mRNA is detected only in the liver (McLellan et al. 1992); in the present study, therefore, we restricted our measurement of IGFBP-1 mRNA levels to that in liver tissue. 


\section{A. Right Heart}

CONTROL

\section{UCO}

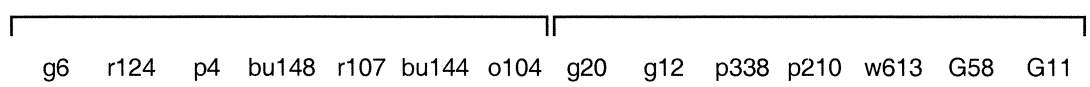

$1.7 \mathrm{~kb}=$

$1.4 \mathrm{~kb}=$

$18 S$
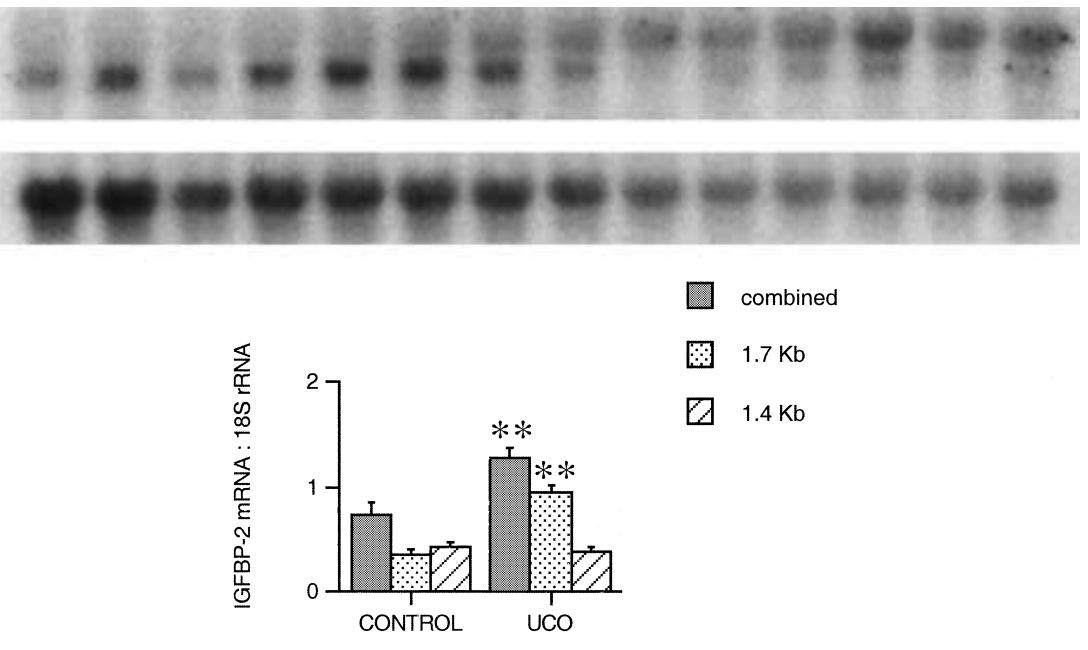

B. Kidney

CONTROL
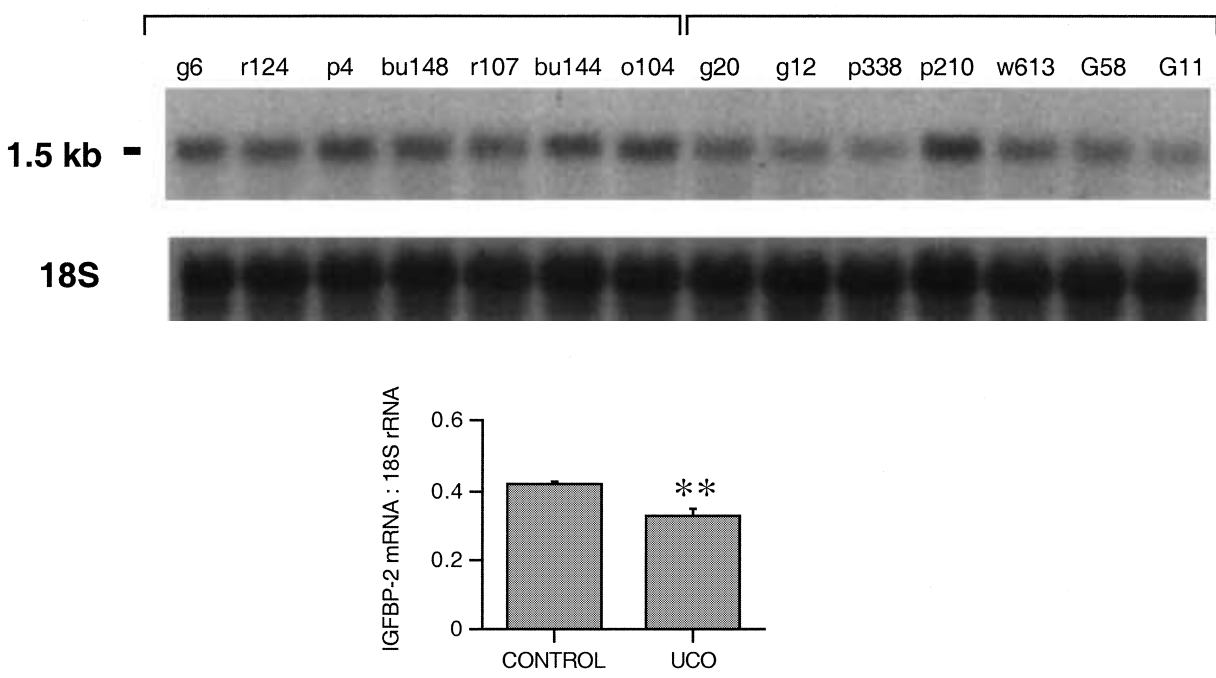

Figure $5 \mathrm{~A}$ and $\mathrm{B}$. 


\section{Right Liver}

\section{CONTROL UCO}

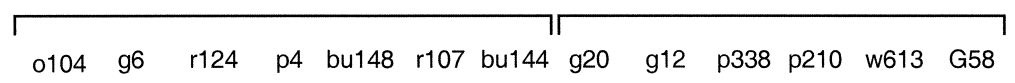

$1.5 \mathrm{~kb}$

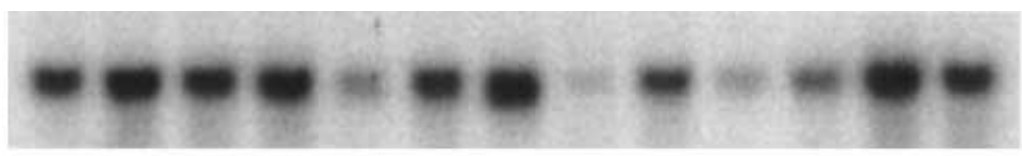

$18 S$
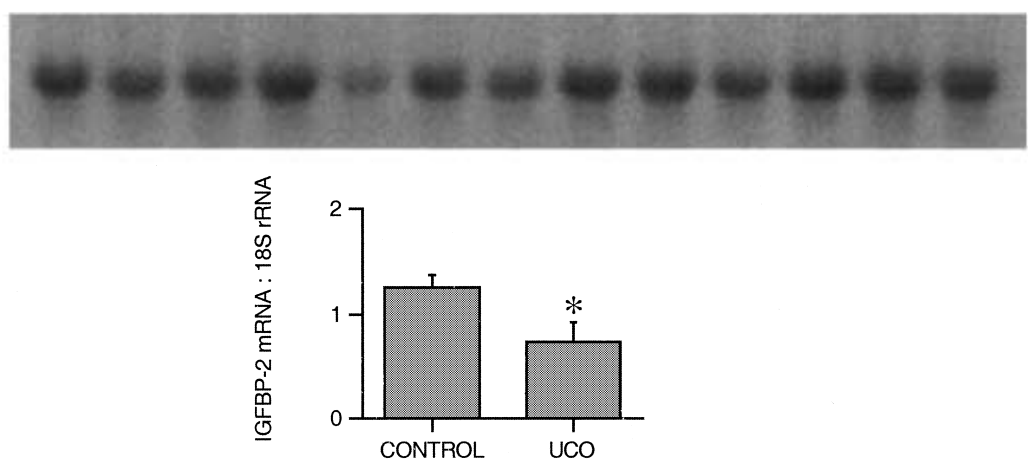

\section{Placenta}

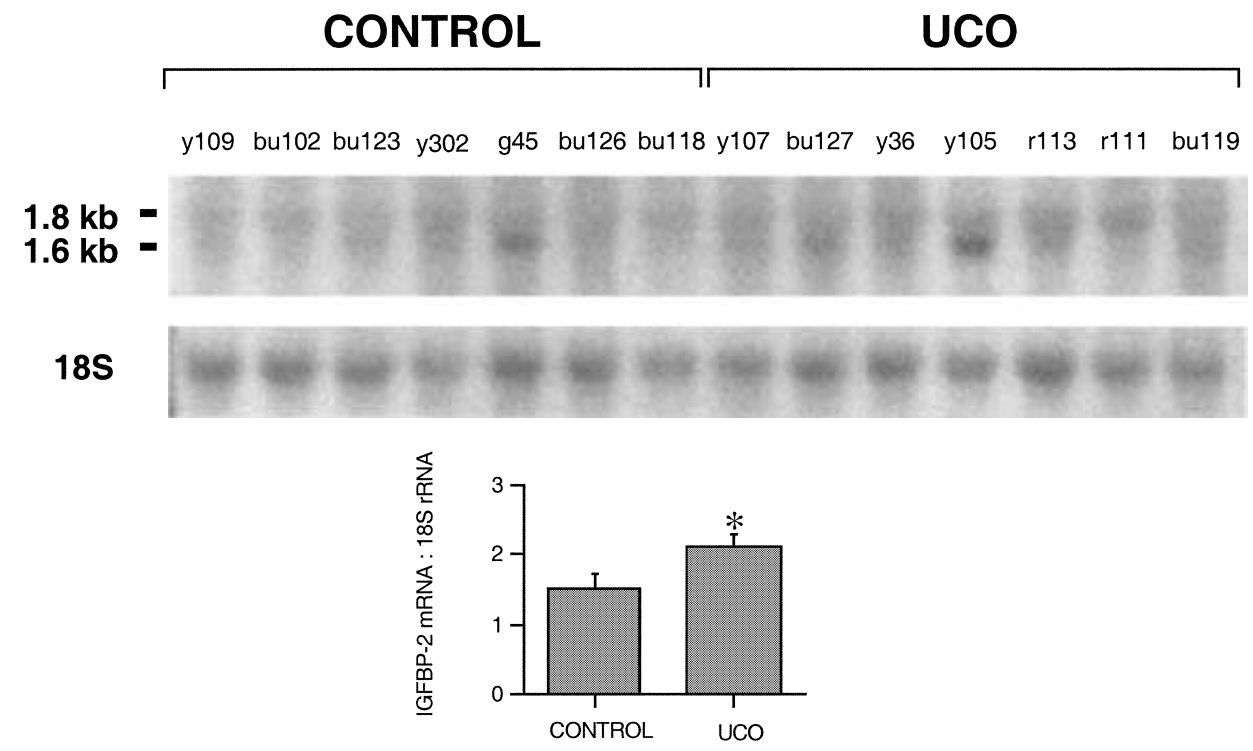

Figure $5 \mathrm{C}$ and $\mathrm{D}$.

Figure 5 Northern blot hybridization of total RNA (20 $\mu$ g per lane) from preterm right heart (A), preterm kidney (B), preterm right liver (C), and near-term placenta (D) of control and UCO fetuses with ${ }^{32}$ P-labelled ovine IGFBP-2 (upper panels) and 18S rRNA (lower panels) cDNA. A single IGFBP-2 mRNA transcript $(\sim 1.5 \mathrm{~kb})$ was observed in $(B)$ and $(C)$, whereas two transcripts were detected in $(A)$ and $(D)$ $(1.6$ and $1.8 \mathrm{~kb})$. Graphs show the results of densitometric analysis (means \pm S.E.M. values). The abundance of IGFBP-2 mRNA (expressed as a ratio to $18 \mathrm{~S}$ rRNA) was lower in preterm kidneys $\left({ }^{* *} P<0 \cdot 01\right)$ and right livers $\left({ }^{*} P<0 \cdot 05\right.$ ), but higher in right hearts (preterm, ${ }^{* *} P<0 \cdot 01$ ) and placentas (near term, ${ }^{*} P<0 \cdot 05$ ) of UCO fetuses relative to control fetuses. Numbers above lanes identify individual animals. Note: total RNA

samples from the right liver of one UCO-group fetus was consistently found to be degraded and therefore was not included in the Northern blot. 

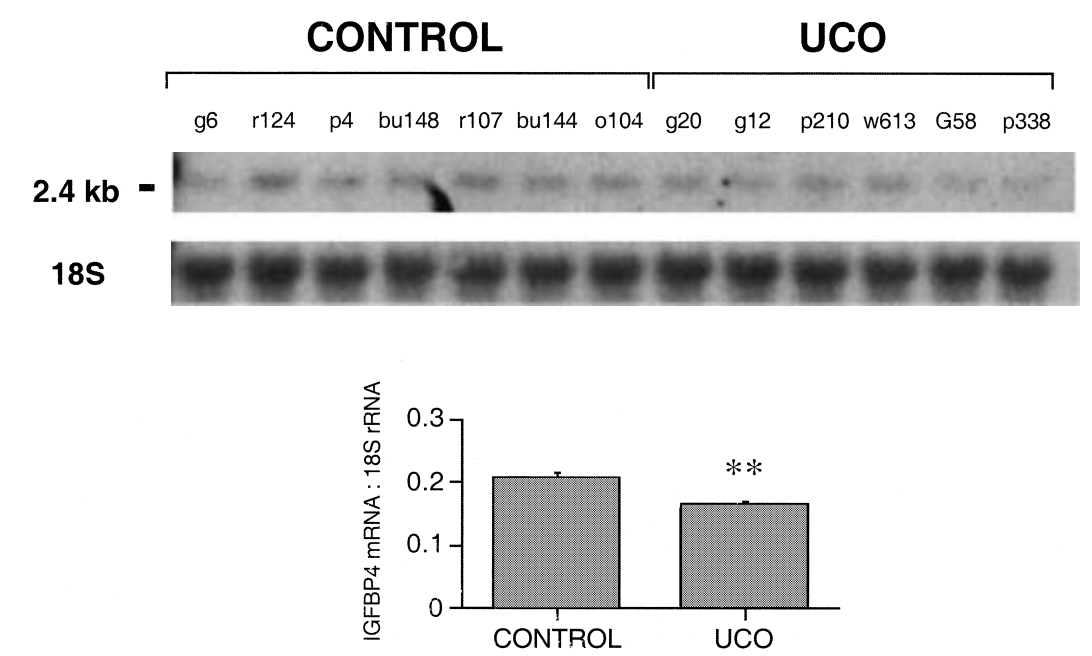

Figure 6 Northern blot hybridization of total RNA (20 $\mu \mathrm{g}$ per lane) from preterm skeletal muscle of control and UCO fetuses with ${ }^{32} \mathrm{P}$-labelled ovine IGFBP-4 (upper panel) and $18 \mathrm{~S}$ rRNA (lower panel) cDNA. A single IGFBP-4 mRNA transcript was observed at $\sim 2.4 \mathrm{~kb}$. The graph shows that the abundance of IGFBP-4 mRNA, expressed as a ratio to $18 \mathrm{~S}$ rRNA, was lower in UCO fetuses than in control fetuses $\left({ }^{* *} P<0 \cdot 01\right)$, according to densitometric analysis (means \pm S.E.M. values). Numbers above lanes identify individual animals. Note: total RNA samples from one of the UCO-group fetuses was consistently found to be degraded and therefore was not included in the Northern blot.

Densitometric analysis of IGFBP-1 and IGFBP-3 mRNA transcripts showed no differences between control and UCO fetuses in any of the tissues examined from both the preterm and the near-term group fetuses (Table 2). The kidney and the liver expressed a single IGFBP-2 mRNA transcript $(\sim 1.5 \mathrm{~kb}$. Fig. $5 \mathrm{~B}$ and $\mathrm{C}$ respectively), whereas preterm right ventricle and near-term placenta expressed two transcripts $(\sim 1.4$ and $1.7 \mathrm{~kb}$. Fig. $5 \mathrm{~A}$ and $\mathrm{D}$ respectively). IGFB-2 mRNA was most abundant in the liver and kidney of both preterm and near-term groups. In UCO fetuses of the preterm group, IGFBP-2 mRNA levels were greater in the right ventricle $(72 \%)$, but lower in the liver (42\%) and the kidney (22\%). In UCO fetuses of the near-term group, IGFBP-2 mRNA levels were greater in placental tissue (39\%) (Fig. 5 and Table 2). In UCO fetuses of the preterm group, skeletal muscle was the only tissue that showed a decrease in IGFBP-4 mRNA (21\%; Fig. 6 and Table 2).

\section{Discussion}

In the present study, we found no significant differences in the plasma levels of IGF-I, IGF-II or IGFBPs between control and UCO fetuses. IGFs are paracrine/autocrine, rather than endocrine, factors (Han et al. 1988, Delhanty \& Han 1993, Yakar et al. 1999) and therefore plasma concentrations reflect synthesis by all tissues of the fetus. Previous studies have demonstrated that $3 \mathrm{~h}$ of fetal hypoxia with acidosis produced by reduction of maternal inspired oxygen (Iwamoto et al. 1992), but not $24 \mathrm{~h}$ of continuous fetal hypoxia induced by reduced uterine blood flow (McLellan et al. 1992), causes a fall in plasma IGF-I levels with no change in IGF-II levels. However, both Iwamoto et al. (1992) and McLellan et al. (1992) observed a dramatic elevation in plasma IGFBP-1. Differences between these studies and the present work include the intensity and duration of the stimulus.

IGF-I and -II mRNA and IGFBP mRNAs were detectable in all tissues examined, with the exception of IGFBP-1 (which is only expressed in the liver). As we have reported previously, the abundance of IGF-II was greater than that of IGF-I, and IGFBP2 mRNA levels were highest in the liver and the kidney (Delhanty \& Han 1993). UCO reduced the abundance of IGF-II mRNA, but not of IGF-I mRNA, in selected tissues from the preterm group (111-116 days of gestation). In contrast, $24 \mathrm{~h}$ of restricted uterine blood flow (RUBF) in ovine fetuses aged between 115 and 120 days of gestation resulted in a significant decline in liver IGF-I mRNA and only a tendency for IGF-II mRNA to decrease (McLellan et al. 1992). We observed no changes in tissue IGF-I or -II mRNA levels in the near-term group in response to UCO, although previous work in late-gestation (126-130 and 134-136 days of gestation) ovine fetuses has shown that $48 \mathrm{~h}$ of acute isocapnic hypoxia reduced IGF-II mRNA expression in the adrenal gland (Braems et al. 1998). Our results suggest a greater susceptibility of IGF-II gene expression to UCO in younger fetuses, in which IGF-II mRNA levels are higher (Delhanty \& Han 1993). 
We found no differences in hepatic IGFBP-1 mRNA abundance between control and UCO fetuses from preterm or near-term groups, in contrast to our previous finding of a 3-7-fold elevation of hepatic IGFBP-1 mRNA levels following $24 \mathrm{~h}$ of continuous fetal hypoxia (McLellan et al. 1992). Recently, it was demonstrated that the human IGFBP-1 gene contains HRE sequences in the intron 1 region, which can be induced by either hypoxia or hypoxia-inducible factor-1 (HIF-1) (Tazuke et al. 1998) and thus it is possible that either the ovine IGFBP-1 gene does not contain HREs or that the sequences are induced by sustained, and not acute, hypoxia.

We detected two IGFBP-2 mRNA transcripts in the preterm right heart and near-term placenta which appear to be differentially regulated, with an increase in the $1.7 \mathrm{~kb}$ transcript and no change in the $1.4 \mathrm{~kb}$ transcript in UCO fetuses. The cause of the two transcripts is unknown, but could be the result of a post-transcriptional modification or variations in polyadenylation. Others have observed two transcripts in the brains of 21-day-old rats made hypoxic by carotid artery ligation (Klempt et al. 1993). The abundance of IGFBP-2 mRNA decreased in the preterm right liver and kidney as in previous studies using $24 \mathrm{~h}$ hypoxia (McLellan et al. 1992), and increased in the preterm right ventricle of the heart and near-term placenta of UCO fetuses. The alteration in IGFBP-2 gene expression with UCO in preterm compared with near-term fetuses may be due to changes in gene transcription.

A number of factors could be responsible for the alterations in IGF and IGFBP gene expression in the present study. Already, we have demonstrated that UCO produces a reversible fetal asphyxia, bradycardia and a rise in blood pressure in these fetuses (Green et al. 1999, Kawagoe et al. 1999). In addition, previous work has shown a redistribution of blood flow, favouring the brain and heart at the expense of, for example, the skeletal muscle during UCOs of different intensities and duration (Richardson et al. 1996, Giussani et al. 1997). Therefore it is possible that differences in oxygen/nutrient delivery to specific organs could have differentially affected IGF/ IGFBP gene expression.

In addition, UCO produces changes in a number of hormone systems that could impact on the control of the IGF-axis. Plasma catecholamines are elevated by UCO in the near-term fetal sheep (Smith et al. 1991) and are implicated in the increased synthesis and release of IGFBP-1 during prolonged fetal hypoxia (Hooper et al. 1994). Cortisol has been shown to suppress IGF-II gene expression in the liver ( $\mathrm{Li}$ et al. 1993) and the adrenal gland (Lü et al. 1994). We have reported previously that plasma cortisol is increased to a variable extent by $\mathrm{UCO}$ in the fetuses involved in the present study (Green et al. 1997), and therefore it is possible that this altered circulating cortisol contributed to the tissue-specific decline in IGF-II.
IGFBP-2 is a membrane-bound and -soluble binding protein that normally functions to facilitate the action of IGFs (Gluckman 1995). Therefore, a decline in IGFBP-2 mRNA abundance in the liver and the kidney could lead to a condition whereby IGFBP-2 is reduced at local tissue level to reduce growth in these tissues in response to tissue-specific decreases in blood flow/oxygen uptake during hypoxia. Similarly, the increase in IGFBP-2 mRNA in the heart might indicate a potentiation of growth when combined with the tendency for blood flow to increase as a result of UCO (Richardson et al. 1996). IGFBP-2 mRNA is expressed in the dense caruncular-like stroma lining the luminal epithelium and the placentome capsule (Reynolds et al. 1997), and therefore the increase in placental IGFBP-2 mRNA in the near-term fetuses of the present study may have been a form of compensation in the placenta when blood flow was compromised acutely by UCO. We have also observed a decline in IGFBP-4 in the skeletal muscle of preterm UCO fetuses. The control of ovine fetal IGFBP-4 has been linked to IGF-I (Carr et al. 1995), and IGFBP-4 may be involved in modulating the action of IGF-II produced by the invading trophoblast in the guinea-pig placenta (Han et al. 1999). In the lung and skeletal muscle, the observed decrease in IGF-II mRNA levels suggests a move towards reduced growth in tissues; it is interesting that these tissues are some of those in which blood flow and growth are sacrificed during hypoxic challenges.

In conclusion, we have demonstrated that repetitive UCO over a period of days does not alter fetal body or organ weight but does produce tissue-specific alterations in components of the IGF system which were not reflected in circulating plasma levels and which were confined primarily to the preterm group. We speculate that altered IGFBP-2 mRNA levels and reduced IGF-II mRNA levels in selected tissues may be early indicators of changes in growth.

\section{Acknowledgements}

This work was supported by grants from the Medical Research Council of Canada. L R G and Y K were funded by postdoctoral fellowships from the Medical Research Council of Canada and The Lawson Research Institute. B S R, V H and D H are members of the Medical Research Council Group in Fetal and Neonatal Health and Development. B S R is the recipient of the WyethAyerst Canada, Inc. Clinical Research Chair in Women's Health for Perinatology.

\section{References}

Anyaegbunam A, Brustman L, Divon M \& Langer O 1986 The significance of antepartum variable decelerations. American Journal of Obstetrics and Gynaecology 155 707-710. 
Asano H, Han VK, Homan J \& Richardson BS 1997 Tissue DNA synthesis in the preterm ovine fetus following $8 \mathrm{~h}$ of sustained hypoxemia. Journal for the Society of Gynecologic Investigation $\mathbf{4}$ 236-240.

Barker D 1994 Mothers, Babies and Disease in Later Life, pp 121-139. London: BMJ Publishing Group.

Braems GA, Han VKM \& Challis JRG 1998 Gestational agedependent changes in the levels of mRNAs encoding cortisol biosynthetic enzymes and IGF-II in the adrenal gland of fetal sheep during prolonged hypoxemia. Journal of Endocrinology 159 257-264.

Carr JM, Owens JA, Grant PA, Walton, PE, Owens PC \& Wallace JC 1995 Circulating insulin-like growth factors (IGFs), IGF-binding proteins (IGFBPs) and tissue mRNA levels of IGFBP-2 and IGFBP-4 in the ovine fetus. Journal of Endocrinology 145 545-557.

Chomczynski P \& Sacchi N 1987 Single-step method of RNA isolation by acid guanidium thiocyanate-phenol-chloroform extraction. Analytical Biochemistry 162 156-159.

Collins JH, Collins CL, Weckwerth SR \& de Angelis L 1995 Nuchal cords: timing of prenatal diagnosis and duration. American Journal of Obstetrics and Gynecology 173768.

Dawes GS, Lobb MO, Mandruzzato G, Moulden M, Redman CWG \& Wheeler T 1993 Large fetal heart rate decelerations at term associated with changes in fetal heart rate variation. American Journal of Obstetrics and Gynecology 168 105-111.

Delhanty PJD \& Han VKM 1992 The characterization and expression of ovine insulin-like growth factor-binding protein-2. Journal of Molecular Endocrinology 9 31-38.

Delhanty PJD \& Han VKM 1993 The expression of insulin-like growth factor (IGF)-binding protein-2 and IGF-II genes in the tissues of the developing ovine fetus. Endocrinology 132 41-52.

Giudice LC, de Zegher F, Gargosky SE, Dsupin BA, de las Fuentes L, Crystal RA, Hintz RL \& Rosenfeld RG 1995 Insulin-like growth factors and their binding proteins in the term and preterm human fetus and neonate with normal and extremes of intrauterine growth. Journal of Clinical Endocrinology and Metabolism $\mathbf{8 0}$ 1548-1555.

Giussani DA, Unno N, Jenkins SL, Wentworth RA, Derks JB, Collins JH \& Nathanielsz PW 1997 Dynamics of cardiovascular responses to repeated partial umbilical cord compression in lategestation sheep fetus. American Journal of Physiology 273 H2351-H2360.

Gluckman PD 1995 Insulin-like growth factors and their binding proteins. In Fetus and Neonate, Physiology and Clinical Implications, vol 3, edn 1, pp 97-115. Eds MA Hanson, JAD Spencer \& CH Rodeck. Cambridge: Cambridge University Press.

Green LR, Homan J, Fraser M, Challis JRG \& Richardson B 1997 The ACTH and cortisol response to umbilical cord occlusion in the ovine fetus is altered with repetitive insults. Journal of the Society for Gynecologic Investigation 4 p 80A, Abstract 008.

Green LR, White S, Kawagoe Y \& Richardson BS 1999 Cardiovascular and metabolic responses to intermittent umbilical cord occlusion in the preterm ovine fetus. Journal of the Society for Gynecologic Investigation 6 56-63.

Han VKM \& Hill DJ 1994 Growth factors in fetal growth. In The Textbook of Fetal Physiology pp 48. Eds GD Thornurn \& R Harding. Oxford: Oxford Medical Publications.

Han VKM, Lund PK, Lee DC \& D'Ercole AJ 1988 Expression of somatomedin/insulin-like growth factor messenger ribonucleic acids in the human fetus: identification, characterization, and tissue distribution. Journal of Clinical Endocrinology and Metabolism 66 422-429.

Han VKM, Carter AM, Chandarana S, Tanswell B \& Thompson K 1999 Ontogeny of expression of insulin-like growth factor (IGF) and IGF binding protein mRNAs in the guinea-pig placenta and uterus. Placenta 20 361-377.

Hayatsu J, Asano H \& Han VKM 1994 Ovine IGF binding protein-3: molecular cloning and developmental expression. Growth Regulation 4 S-98.
Hooper SB, Bocking AD, White S, Chaliis JR \& Han VK 1991 DNA synthesis is reduced in selected fetal tissues during prolonged hypoxemia. American Journal of Physiology 261 R508-R514.

Hooper SB, Bocking AD, White SE, Fraher LJ, McDonald \& Han VKM 1994 Catecholamines stimulate the synthesis and release of insulin-like growth factor binding protein-1 (IGFBP-1) by fetal sheep liver in vivo. Endocrinology 134 1104-1112.

Iwamoto HS, Murray MA \& Chernausek SD 1992 Effects of acute hypoxemia on insulin-like growth factors and their binding proteins in fetal sheep. American Journal of Physiology 263 E1151-E1156.

Jennett RJ, Warford HS, Kreinick C \& Waterkotte GW 1981 Apgar index: a statistical tool. American Journal of Obstetrics and Gynecology 140 206-212.

Kawagoe Y, Green L, White S \& Richardson B 1999 Intermittent umbilical cord occlusion in the ovine fetus near term: effects on behavioural activity. American Journal of Obstetrics and Gynaecology 181 1520-1529.

Klempt M, Klempt ND \& Gluckman PD 1993 Hypoxia and hypoxia/ ischemia affect the expression of insulin-like growth factor binding protein 2 in the developing rat brain. Molecular Brain Research 17 347-350.

Li J, Saunders JC, Gilmour RS, Silver M \& Fowden AL 1993 Insulin-like growth factor-II messenger ribonucleic acid expression in fetal tissues of the sheep during late gestation: effects of cortisol. Endocrinology 132 2083-2089.

Lü F, Han VKM, Milne WK, Fraser M, Carter AM, Berdusco ETM \& Challis JRG 1994 Regulation of insulin-like growth factor-II gene expression in the ovine fetal adrenal gland by adrenocorticotropic hormone and cortisol. Endocrinology 134 2628-2635.

McCrabb GJ, Egan AR \& Hosking BJ 1991 Maternal undernutrition mid-pregnancy in sheep. Placental size and its relationship to calcium transfer during late pregnancy. British Journal of Nutrition 65 $157-168$.

McLellan KC, Hooper SB, Bocking AD, Delhanty PJD, Philips ID, Hill DJ \& Han VKM 1992 Prolonged hypoxia induced by reduction of maternal uterine blood flow alters insulin-like growth factor-binding protein-1 (IGFBP-1) and IGFBP-2 gene expression in the ovine fetus. Endocrinology 131 1619-1628.

Osak R, Webster KM, Bocking AD, Campbell MK \& Richardson BS 1997 Nuchal cord evident at birth impacts on fetal size relative to that of the placenta. Early Human Development 49 193-202.

Owens JA, Kind KL, Carbone F, Robinson JS \& Owens PC 1994 Circulating insulin-like growth factors-I and -II and substrates in fetal sheep following restrition of placental growth. Journal of Endocrinology 140 5-13.

Reynolds TS, Stevenson KR \& Wathes DC 1997 Pregnancy-specific alterations in the expression of the insulin-like growth factor system during early placental development in the ewe. Endocrinology 138 886-897

Richardson BS, Carmichael L, Homan J, Johnston L \& Gagnon R 1996 Fetal cerebral, circulatory, and metabolic responses during heart rate decelerations with umbilical cord compression. American Journal of Obstetrics and Gynecology 175 929-936.

Rosenfeld RG 1997 An endocrinologist's approach to the growth hormone-insulin-like growth factor axis. Acta Pediatrica (Suppl) 423 17-19.

Smith FG, Smith BA, Segar JL \& Robillard JE 1991 Endocrine effects of ventilation, oxygenation and cord occlusion in near term fetal sheep. Journal of Developmental Physiology 15133.

Straus DS \& Takemoto CD 1990 Effect of dietary protein deprivation on insulin-like growth factor (IGF)-I and -II, IGF binding protein-2, and serum albumin gene expression in rat. Endocrinology 127 $1849-1860$

Tazuke SI, Mazure NM, Sugawara J, Carland G, Faessen GH, Suen L-F, Irwin JC, Powell DR, Garccia AJ \& Giudice LC 1998 Hypoxia stimulates insulin-like growth factor binding protein 1 
(IGFBP-1) gene expression in HepG2 cells: A possible model for IGFBP-1 expression in fetal hypoxia. PNAS 95 10188-10193.

Verhaeghe J, Van Bree R, Van Herck E, Laureys J, Bouillon R \& Van Assche FA 1993 C-peptide, insulin-like growth factors I and II, and insulin-like growth factor binding protein-1 in umbilical cord serum: correlations with birth weight. American Journal of Obstetrics and Gynecology 169 89-97.

Vileisis RA \& D’Ercole AJ 1986 Tissue and serum concentrations of somatomedin-C/insulin-like growth factor I in fetal rats made growth retarded by uterine artery ligation Pediatric Research $\mathbf{2 0}$ 126-130.
Wang HS, Lim J, English J, Irvine L \& Chard T 1991 The concentration of insulin-like growth factor-I and insulin-like growth factor-binding protein-1 in human umbilical cord serum at delivery: relation to fetal weight. Journal of Endocrinology 129 459-464.

Yakar S, Liu J-L, Stannard B, Butler A, Accili D, Sauer B \& LeRoith D 1999 Normal growth and development in the absence of hepatic insulin-like growth factor I. PNAS 96 7324-7329.

Received 11 February 2000

Accepted 4 May 2000 